\title{
Antibiotic activity of marine microorganisms: the antibacterial spectrum
}

\author{
Roshan B. Baam, Naren M. Gandhi and Yvonne M. Freitas \\ Microbiology Department, St. Xavier's College, Bombay, India
}

KURZFASSUNG: Antibiotische Aktivität mariner Mikroorganismen: Das antibakterielle Spektrum. Das antibakterielle Spektrum von sechzig Antibiotika produzierenden Mikroorganismen mariner Herkunft wurde bestimmt. Zwanzig verschiedene Bakterienarten dienten als Testorganismen; von ihnen waren fünfzehn gramnegativ, vier grampositiv und eine Art "säurefest“.

\section{INTRODUCTION}

Ever since the discovery of antibiotic-producing organisms, it has been a well recognized fact that these antagonistic forms vary greatly in their activity against bacteria and other organisms. Some are active against bacteria and others against fungi, while there are still others which may be active against only a few grampositive or a few gram-negative forms of bacteria. Since this considerable degree of variation occurs in the antibiotic activity of different antagonists, it is necessary in any antibiotic study that the broad spectrum analysis occupies an important and essential position.

BEARd \& MEAdowcroft (1935) and ZoBell (1936) found sea water to be bactericidal for many non-marine bacteria, gram-positive forms being more sensitive than gram-negative ones. RoseNFeld \& ZoBell (1947) observed that the response of test organisms to inhibition by marine organisms appeared to parallel the gram reaction and noted, in accordance with the general observations, that gram-positive bacteria were more often inhibited by sea water than the gram-negative species.

\section{EXPERIMENTS}

In order to study the antibacterial spectrum of the marine antagonists, twenty test organisms were employed, four of which were gram-positive pathogens, fifteen gram-negative organisms, four being pathogens of fish, and one an acid fast bacterium. Among the fish pathogens, two were proved to be pathogenic for Tilapia species and Glypbidodon sordidus, while the other two were isolated from diseased fish but did not satisfy Koch's postulates (AlmeIDa 1962). The test organisms selected are given in Table 1. 
Table 1

Antibacterial spectrum of sixty marine isolates (F.D.A.: Food and Drugs Administration, U.S.A.; A.T.C.C.: American Type Culture Collection; N.C.T.C.: National Collection of Type Cultures; P.W.: Park Williams; P. I.: Pasteur Institute)

\begin{tabular}{|c|c|c|c|c|c|c|}
\hline \multirow[t]{2}{*}{ Test organisms } & \multicolumn{3}{|c|}{$\begin{array}{l}\text { Zones of inhibition } \\
\text { in mm }\end{array}$} & \multirow{2}{*}{ 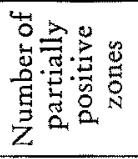 } & \multirow{2}{*}{ 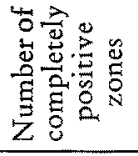 } & \multirow[t]{2}{*}{ Origin } \\
\hline & 0 & $10-20$ & $20-30$ & & & \\
\hline Staphylococcus aurens & 3 & 56 & 1 & 47 & 10 & F.D. A. 209 \\
\hline $\begin{array}{l}\text { Streptococcus } \\
\text { haemolyticus (Gr. A) }\end{array}$ & 11 & 10 & 39 & 5 & 44 & A.T.C.C. 8668 \\
\hline $\begin{array}{l}\text { Diplococcus pneumoniae } \\
\text { (Type II) }\end{array}$ & 9 & 12 & 39 & 10 & 41 & N.C. T. C. 7466 \\
\hline $\begin{array}{l}\text { Corynebacterium } \\
\text { diphtheriae }\end{array}$ & 20 & 17 & 23 & 17 & 23 & P.W. 8 Strain \\
\hline Salmonella typhosa & 2 & 58 & - & 4 & 54 & Ty 2 Strain \\
\hline Salmonella paratyphi (A) & 23 & 23 & 14 & 6 & 31 & N.C.T.C. 5702 \\
\hline Salmonella paratyphi (B) & 30 & 30 & - & 11 & 19 & \\
\hline $\begin{array}{l}\text { Shigella dysenteriae } \\
\text { var. SHIGA }\end{array}$ & 54 & 6 & - & 4 & 2 & N.C.T.C. 8005 \\
\hline $\begin{array}{l}\text { Shigella paradysenteriae } \\
\text { var. FLEXNER }\end{array}$ & 29 & 31 & - & 20 & 11 & N.C.T.C. 8182 \\
\hline $\begin{array}{l}\text { Eschericbia coli } \\
\text { var. communis }\end{array}$ & 52 & 8 & - & 7 & 1 & N.C.T.C. 86 \\
\hline Aerobacter aerogenes & 58 & 2 & - & 2 & - & N.C.T.C. 8172 \\
\hline Proteus vulgaris & 60 & - & - & - & - & N.C. T. C. 5821 \\
\hline Pseudomonas aeruginosa & 60 & - & - & - & - & Local Strain \\
\hline Klebsiella pneumoniae & 50 & 10 & - & 9 & 1 & N.C. T. C. 201 \\
\hline Vibrio cholerae & 55 & 3 & 2 & 1 & 4 & 1800/1 P.I. \\
\hline Pseudomonas aeruginosa & 60 & - & - & - & - & (Fish pathogen) \\
\hline Aeromonas sp. & 53 & 7 & - & 3 & 4 & (Fish pathogen) \\
\hline Pseudomonas sp. & 60 & - & - & - & - & (Fish pathogen) \\
\hline Alginomonas sp. & 60 & - & - & $\rightarrow$ & - & (Fish pathogen) \\
\hline Mycobacterium phlei & 50 & 10 & - & 1 & 9 & N.C.T.C. 8151 \\
\hline
\end{tabular}

All maintenances and tests involving the gram-positive pathogens were carried out on blood agar medium; 24-hour-broth cultures grown in blood broth were used. Nutrient agar and nutrient broth were utilized for all work on gram-negative test organisms, except for the four fish pathogens, for which fish infusion agar and broth were used. For stodk cultures of Mycobacterium phlei and testing of its sensitivity to the antagonists, glycerol-yeast-beef-extract agar and its corresponding broth were used.

For all assay purposes, the agar cup method was resorted to. This method was first employed by RuEHLE \& BREWER (1931) for measuring antiseptics qualitatively. The medium used throughout was WILKIN's agar (1949). The antagonists were grown 
in the most stimulatory liquid medium on the basis of media studies (BAAM 1962) and then assayed against the twenty test organisms. In the case of the acid fast organism, Heatrey's (1944) cylinder plate method was followed. The data obtained have been summarised in Table 1.

\section{RESULTS AND DISCUSSION}

Different spectrum patterns were observed among the sixty isolates tested, corroborating the observations of BRILLIANTINE (1953), BALDWIN et al. (1955) that many different types of antibiotics are produced by different strains of one and the same species.

A fact noted in accordance with the general observations of RosenfELD \& ZoBELL (1947) was that the gram-positive organisms were more often inhibited than the gramnegative forms. It was observed that thirty four of the sixty isolates inhibited all the four gram-positive organisms. Another interesting observation was that rather significant zones of inhibition (ranging from 17 to $30 \mathrm{~mm}$ ) against Streptococcus baemolyticus, Corynebacterium diphtheriae and Diplococcus pneumoniae were obtained with many of the isolates.

Although it was observed during the media studies (BAAM, GANDHI \& FreItAs 1966) that significant inhibitory zones were obtained in most cases with the gramnegative test organism Salmonella typhosa, during spectrum determination it was noted that the gram-negative forms were not as susceptible to marine antagonists as were the gram-positive organisms.

No antibiotic activity was exhibited by any of the sixty isolates against Proteus vulgaris, Pseudomonas aeruginosa and three of the four fish pathogens, namely, Pseudomonas aeruginosa and the organisms of the genera Pseudomonas and Alginomonas.

It has been noted that the enteric and the coliform bacteria perish more rapidly in the sea, and these studies help to demonstrate that the most important single factor in reducing these adventitious organisms in sea water could be a biological one: the antibacterial substances elaborated by the marine bacteria.

\section{SUMMARY}

1. The antibacterial spectrum of sixty marine bacteria was determined using twenty test organisms.

2. Gram-positive organisms were in general found to be more susceptible to antibiotics produced by marine bacteria than the gram-negative forms.

3. The production of antibacterial substances by marine bacteria may be one of the factors responsible for the rapid reduction in number of adventitious organisms entering the marine environment. 


\section{LITERATURE CITED}

Almerda, L. J., 1962. Studies on the microorganisms associated with the diseases of fish. Bombay, M. Sci. Thesis.

BAAM, R. B., 1962. Studies on the production of antibiotics by microorganisms from marine sources. Bombay, M. Sci. Thesis.

-, GandHI, N. M. \& Freitas, Y. M., 1966. Antibiotic activity of marine microorganisms I. Helgoländer wiss. Meeresunters. 13 (in press).

Baldwin, C. L., Peters, B., North, C. \& Nash, H. A., 1955. A study of antibiotic producing bacteria from the soil. Antibiotics Chemother. 5 (3), 145-151.

BEARD, P. J. \& MEADOwCROFT, N. F., 1935. Survival and rate of death of intestinal bacteria in sea water. Am. J. publ. Hith 25, 1023-1026.

Brilliantine, L., 1953. A survey of aerobic spore-forming bacilli isolated from soil as potential sources of antibiotic substances. Antibiotics Chemother. 3, 1235-1238.

Florey, H. W., Chain, E., Heatly, N. G., Jennings, M. A., Sanders, A. G., Abraham, E. P. \& Florey, N. E., 1949. Antibiotics. Oxford Med. Publ., London, Vol, 1, 2.

Heatley, N. G., 1944. A method for the assay of penicillin. Biochem. J. 58, 61-65.

Rosenfeld, W. D. \& ZoBeli, C. E., 1947. Antibiotic production by marine microorganisms. J. Bact. 54 (3), 393-398.

Ruehle, G. L. A. \& Brewer, C. M., 1931. Cited by Florey, H. W. (a. o.), 1949.

Wilkins, W. H, 1949. Ann. appl. Biol. 36, 257.

ZoBelc, C. E., 1936. Bactericidal action of sea water. Proc. Soc. exp. Biol. Med. 34, 113-116. 